\title{
Histological analysis of short-term vital reactions in skin wounds: potential applications in forensic work
}

\author{
Obac, AR. ${ }^{a *}$, Carvalho, EG. ${ }^{b}$, Silva, PCS. ${ }^{c}$, Fenerich-Verani, $N .^{d}$ and Almeida, M. ${ }^{e}$ \\ aUniversidade Federal de São Paulo - UNIFESP, Rua Borges Lagoa, 908, Vila Clementino, São Paulo, SP, Brazil

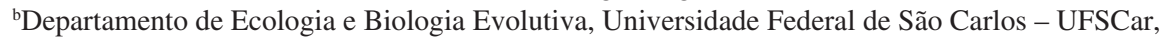 \\ Rod. Washington Luís, Km 235, CP 676, CEP 13605-905, São Carlos, SP, Brazil \\ ${ }^{\mathrm{c}}$ Departamento de Patologia, Universidade Federal de São Paulo - UNIFESP, \\ Rua Botucatu, 740, Vila Clementino, CEP 04023-900, São Paulo, SP, Brazil \\ dDepartamento de Hidrobiologia, Universidade Federal de São Carlos - UFSCar, \\ Rod. Washington Luís, Km 235, CP 676, CEP 13605-905, São Carlos, SP, Brazil \\ 'Departamento de Medicina Legal, Universidade Federal de São Paulo - UNIFESP, \\ Rua Botucatu, 740, Vila Clementino, CEP 04023-900, São Paulo, SP, Brazil \\ *e-mail: alexobac@hotmail.com
}

Received July 20, 2010 - Accepted October 1, 2010 - Distributed November 30, 2011

(With 1 figure)

\begin{abstract}
In forensic medical work, in cases with homicide suspicion, it is important to be able to determine with the greatest possible precision when injuries occurred and whether during vital, or post-mortem conditions. Although several markers of vitality can be employed, it has been attested that components of the extra-cellular matrix, such as fibrin, are among the earliest to be evidenced. In the present study, the histological-histochemical Mallory's Trichrome staining method, previously selected was tested to determine the presence of vital reaction in Wistar rats through fibrin accumulation by testing three short reaction time intervals: 15,30 and 60 minutes after the skin wound infliction. For all time intervals tested, including the shortest (15 minutes), the presence of fibrin at the edges of the skin wound was evidenced. The accumulation of fibrin was, nevertheless, more pronounced at 30 and 60 minutes after the wound. It could be concluded that fibrin is a good marker for vital reaction and that it can be detected very early, within a few minutes after the injury. It is proposed that histological method coupled to the histochemical staining technique here tested can be incorporated into routine forensic work as a tool for evidencing the existence or not of vital reaction.
\end{abstract}

Keywords: vital reaction, skin wound, histological analysis, fibrin.

\section{Análise histológica da reação vital em ferimentos da pele em curto intervalo de tempo: aplicações potenciais em trabalho forense}

\begin{abstract}
Resumo
No trabalho médico-forense, um aspecto importante em casos de suspeita de homicídios é a determinação, com a maior precisão possível, de quando ocorreram os ferimentos e se em condições de plena vitalidade ou se post-mortem. Embora diversos marcadores possam ser utilizados para o diagnóstico de vitalidade das lesões, alguns componentes da matriz extracelular, como a fibrina, podem ser os primeiros sinais de reação vital a serem evidenciados. No presente estudo, o método de coloração histológica-histoquímica Tricrômio de Mallory, previamente selecionado, foi testado para determinar a presença de reação vital em ratos Whistar por meio do acúmulo da fibrina, testando-se três tempos curtos de reação: 15,30 e 60 minutos após a realização de ferimento na pele. Para todos os tempos testados, inclusive no tempo mais curto (15 minutos) foi evidenciado o acúmulo da fibrina na região próxima à borda do ferimento. $\mathrm{O}$ acúmulo de fibrina foi, no entanto, mais intenso 30 e 60 minutos após a ocorrência da lesão. Pôde-se concluir que a fibrina é um bom marcador para a reação vital, podendo ser detectada muito cedo, poucos minutos após a ocorrência do ferimento. Propõe-se que a técnica histológica acoplada à técnica histoquímica da coloração pelo Tricrômio de Mallory poderia ser facilmente incorporada à rotina do trabalho médico forense, como ferramenta para evidenciar a existência ou não de reação vital.
\end{abstract}

Palavras-chave: reação vital, ferimento da pele, análise histológica, fibrina. 


\section{Introduction}

When a wound is inflicted on a living organism, a series of events is triggered, called vital reaction. Vital reaction is a complex mechanism, involving a number of phenomena occurring over distinct spatial and temporal scales. Determination of wound vitality and the interpretation of the chronological sequence of events is an important part of the work in forensic medicine. It is important to be able to report with the greatest possible precision when injuries occurred and whether during the vital, or during the postmortem period (Ohshima, 2000; Kondo, 2007).

A characteristic of living tissue is its capacity to respond to external stimuli. When the stimulus is a traumatic aggression whether physical, chemical or biological, the tissue reaction consists essentially of an acute inflammation, usually proportional to the magnitude of the trauma (Cardillo et al., 2005).

Recently it has been shown that since certain reactions do not occur in postmortem wounds, while in life there is a complex and organized sequence of events linked to tissue repair and restoration of the function of injured organs, making it possible to characterize, step by step, morphological and functional stages, and enabling the creation of a model that could be applied to many problems in legal or forensic medicine (Oehmichen and Kirchner 1996; Ortiz-Rey et al., 2002, 2003; Oehmichen, 2004; Kondo, 2007).

The determination of wound age or wound vitality is very important in forensic practice. Analysis of wound vitality markers, such as the inflammatory reaction mediators, are essential for diagnosing the vitality of the lesions and to establish lesion chronology, pre and post-mortem. Although a classical approach, this is still an area of concern in modern forensic medicine and there is a continuous demand for further research and gathering of information to be applied in daily practical work (Grellner and Burkhard, 2007).

Earlier studies carried out by Fatteh $(1966,1971)$ showed that morphological parameters detectable by routine histological methods could be used to estimate wound age in human skin, with valuable applications in legal medicine.

Various molecules can act as markers of vitality. Proteins of the extracellular matrix (fibrinogen, fibrin, fibronectin, tenascin and vitronectin) can be used as markers of vitality at time intervals varying from a few minutes up to 10 hours after the lesion (Oehmichen, 2004). The structural proteins are among the molecules detected earliest at the edge of the wound, in the post-traumatic period and recent work indicates that fibrin can be detected in a time interval as short as 5 minutes after the wound is inflicted (Kondo, 2007).

Fibrin is an important element of the exudate of acute inflammatory responses and can be found wherever there is recent tissue damage. In the injuries performed after fatal trauma, fibrin is very weakly detected being found in trace amounts or artifacts at edge of the wound (Oehmichen and Kirchner, 1996).

Although several techniques are known to be capable of evidencing vital reaction they are of difficult application in the routine legal medical work due to the complexity of analysis or because they are very expensive. Histological and histochemical techniques could be a better approach considering its simplicity and relatively low cost.

In the present study, Mallory's trichrome staining technique was tested regarding its potential to show the vital reaction following skin injuries and the short-term chronology of the wounds using fibrin as a marker of vital reaction.

\section{Materials and Methods}

An experiment to compare the vital reaction intensity was performed at three different time intervals: 15,30 and 60 minutes after injury and non-injured (control). Twelve Wistar rats weighing 200-300 g. were used (3 replicates in each treatment). They were kept in cages, in groups of three for 24 hours before the experiment with free access to food and water. The rats were anesthetised by intramuscular injection of a mixture of ketamine hydrochloride and xylazine hydrochloride in the proportion of 3:2 in a dosage of $0.1 \mathrm{~mL} / 100 \mathrm{~g}$ body weight.

Hair was removed from the rat bellies with a razor and the area washed with physiological solution and dried with sterile cloth. Each animal was anesthetised and a $0.5 \mathrm{~cm}$ long incision was made in the prepared area of skin with a scalpel. After 15 minutes, a $1 \mathrm{~cm}^{2}$ skin sample was removed from the animal in the first group, with the incision at the center. The material was preserved in $10 \%$ formalin. This procedure was then repeated after 30 minutes for the second group and after 60 minutes for the third. The control group was then anesthetised and sacrificed to obtain a post-mortem sample.

The material was subjected to histological analysis, being fixed, stained and sectioned according to standard routine methods in the Histology laboratory of the Department of Hydrobiology, Federal University of São Carlos (UFSCar). The tissue was dehydrated through xylene and hydrated through ethanol series and transferred to xylene $(3 \times 15$ minutes $)$ and subsequently embedded in melted paraffin at $58{ }^{\circ} \mathrm{C}$, for 24 hours at room temperature. Skin samples were oriented parallel to the incision, allowed to harden in paraffin for two days and then cut into $8 \mathrm{~mm}$ sections on a rotary microtome. Serial sections from each specimen were obtained by microtomy and stained by the Mallory's Trichrome method (Bancroft and Stevens, 1996) Serial sections were qualitatively evaluated for the presence of fibrin, using a computer image acquisition system (Carl Zeiss microscope Axioscop 2 plus Axiocam camera). The undamaged margin beside the incision in the control group was used as control and the injured tissue, left to react for various times (15, 30 and 60 minutes after injury) was evaluated for this vital reaction marker.

\section{Results}

Selected skin section images for the reaction time of 30 minutes and for the post-mortem incision are displayed (Figure 1a,b). In the section representing the 30 minutes reaction time the fibrin accumulation at the borders of the incision appears stained in red by the Mallory's Trichrome 


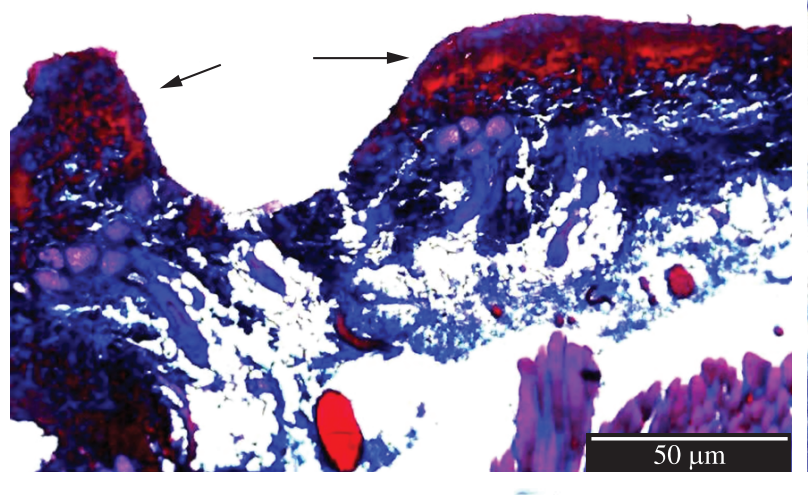

(a)
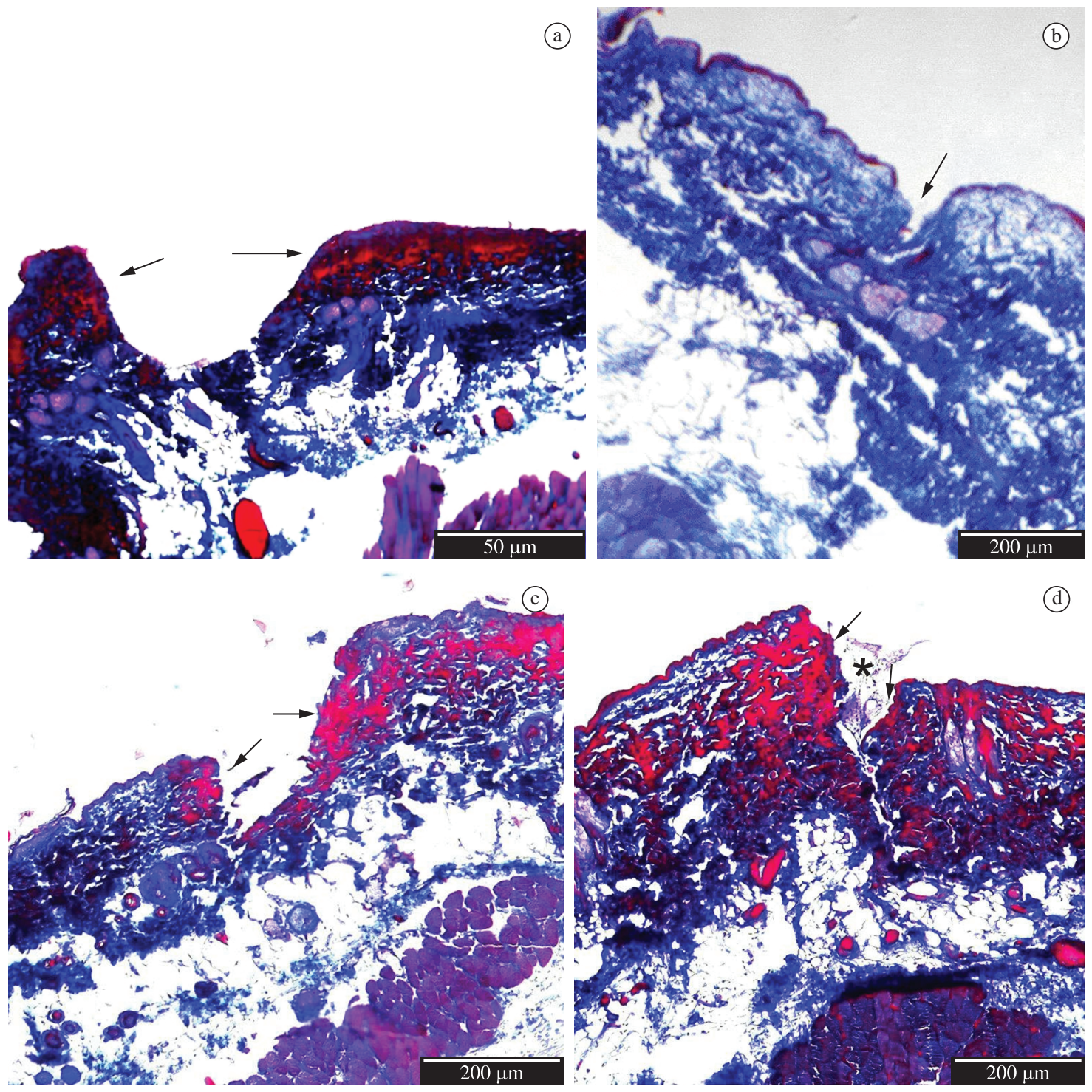

Figure 1. Fibrin accumulation at various vital reaction time intervals as red stained by Mallory's trichrome histochemical method: a) in vivo 30 minutes vital reaction; b) post-mortem (after 30 minutes time interval) skin section stained by Mallory's trichrome; c) in vivo 15 minutes vital reaction; d) in vivo 60 minutes vital reaction. Arrows show the accumulation of fibrin in the wound edge.

stain mixture (Figure 1a); On the other hand, there is no fibrin accumulation in the borders of the incision inflicted after death (Figure 1b) and the whole tissue appears stained in blue.

In the sections taken from rats exposed to 15 minutes vital reaction, it is already possible to observe the accumulation of fibrin at the wound edges (Figure 1c), coloured in red by Mallory's trichome. In the 60 minutes reaction time (Figure 1d), the skin section has a greater accumulation of fibrin at the borders of the incision which is more evident than in the 15 minutes reaction time as indicated by a stronger stained and extended area.

\section{Discussion}

It has been demonstrated that skin-wound healing starts immediately after the injury and consists of a well-orchestrated sequence of events with three phases: inflammation, proliferation and maturation. In our preliminary tests it was possible to observe that all histochemical and histological staining methods used were more efficient at showing presence of fibrin than of mucopolyssacharydes.

Fibrin is an insoluble fibrous protein formed by the polymerisation of fibrinogen, a smaller soluble blood protein. Fibrin is most commonly seen in recently damaged 
tissues and in acute inflammatory reaction, resulting from oozing of fluid and plasma proteins out of damaged skin vessels (Bradbury and Era, 1996). There is an overlap in the early phase of inflammation following trauma and alterations within the first 30 minutes can be regarded as either vital reactions or signs of wound healing (Oehmichen and Kirchner, 1996).

In paraffin sections, fibrin is strongly eosinophilic (Bancroft and Stevens, 1996; Bancroft and Gamble, 2005). In this study, the edge of the wound appeared red in Mallory's trichrome staining showing that fibrin deposition was characteristic of the initial period after the lesion.

A gradual and progressive staining of fibrin due to the vital reaction was observed, which depended on the reaction time. The greatest differences were found when comparing sections from 15 with those with 30 or 60 minutes of reaction. The vital reaction was visible in all sections after the 15 minutes period of reaction, but not in any of those from the post-mortem incision. Vital reaction was present at the edge of the skin wound, and appeared in all three reaction times, indicating that it is feasible to distinguish between lesions performed in vivo from those performed after death even in such short time of vital reactions.

The occurrence of vital reaction was evident in all tests performed. Fibrin was a good marker of vital reaction being present in the skin wounds just 15 minutes after the injury. Most studies in the literature suggested that histochemical markers of vital reaction will only appear some hours after the injury. In this study we found evidence that a vitality marker such as fibrin can be detected much earlier, within a few minutes of the injury, and easily introduced into forensic work.

\section{References}

BANCROFT, JD. and GAMBLE, M. (Eds.)., 2005. Theory and Practice of Histological Techniques. 5nd ed. Edinburgh: Churchill Livingstone. 796 p.

BANCROFT, JD. and STEVENS, A. (Eds.)., 1996. Theory and Practice of Histological Techniques. 4nd ed. Edinburgh: Churchill Livingstone. $766 \mathrm{p}$.
BRADBURY, P. and ERA, K., 1996. Connective Tissues and Stains. In: BANCROFT, JD. and STEVENS, A. (Eds.). Theory and Practice of Histological Techniques. 4nd ed. Edinburgh: Churchill Livingstone. 766 p. chap. 7, p. 113-138.

CARDILLO, GZ., GIMENE, MP. and CAMARGO, RS., 2005. Marcadores inflamatórios aplicados à Medicina. News Lab, vol. 71, p. 116-128.

FATTEH, A., 1966. Histochemical distinction between antemortem and postmortem skin wounds. Journal of Forensic Sciences, vol. 11 , no. 1, p. $17-26$.

-, 1971. Distinction between antemortem and mortem wounds: a study of elastic fiber in human skin. Journal of Forensic Sciences, vol. 16 , no. 3, p. 393-396.

GRELLNER, W. and BURKHARD, M., 2007. Demands on scientific studies: vitality of wounds and wound age estimation. Forensic Science International, vol. 165, no. 2-3, p. 150-154. PMid:16806766. http://dx.doi.org/10.1016/j.forsciint.2006.05.029

KONDO, T., 2007. Timing of skin wounds. Legal Medicine, vol. 9 , no. 2, p. 109-114. PMid:17275383. http://dx.doi.org/10.1016/j. legalmed.2006.11.009

OEHMICHEN, M., 2004. Vitality and time course of wounds. Forensic Science International, vol. 144, no. 2- 3, p. 221-31.

OEHMICHEN, M. and KIRCHNER, H., 1996. The Wound Healing Process - Forensic Pathological Aspects. Lübeck: Schmidt-Römhild.

OHSHIMA, T., 2000. Forensic wound examination. Forensic Science International, vol. 113, no. 1-3, p. 153-164. http://dx.doi. org/10.1016/S0379-0738(00)00269-3

ORTIZ-REY, JA., SUÁREZ-PEÑARANDA, JM., DA SILVA, EA., MUÑOZ, JI., SAN MIGUEL-FRAILE, P., DE LA FUENTE-BUCETA, A. and CONCHIERO-CARROL, L., 2002 Immunohistochemical detection of fibronectin and tenascin in incised human skin injuries. Forensic Science International, vol. 126, p. 118-122. http://dx.doi.org/10.1016/S0379-0738(02)00032-4

ORTIZ-REY, JA., SUÁREZ-PEÑARANDA, JM., MUÑOZBARÚS, JI., ÁLVAREZ, C., SAN MIGUEL, P., RODRÍGUEZCALVO, MS. and CONCHEIRO-CARRO, L., 2003. Expression of fibronectin and tenascin as a demonstration of vital reaction in rat skin and muscle. International Journal of Legal Medicine, vol. 117, no. 6, p. 356-360. PMid:14586623. http://dx.doi. org/10.1007/s00414-003-0403-6 